\title{
Antitumor immunity induced by tumor cells engineered to express a membrane-bound form of IL-2
}

\author{
Mi-Ra Chang ${ }^{1}$, Woong-Hee Lee ${ }^{2}$, \\ Jin-Wha Choi ${ }^{1}$, Sun-Ok Park ${ }^{1}$, \\ Sang-Gi Paik ${ }^{2}$ and Young Sang Kim ${ }^{1,3}$ \\ ${ }^{1}$ Department of Biochemistry \\ ${ }^{2}$ Department of Biology \\ College of Natural Sciences, Chungnam National University \\ Daejeon 305-764, Republic of Korea \\ ${ }^{3}$ Corresponding author: Tel, 82-42-821-5487; \\ Fax, 82-42-822-7548; E-mail, young@cnu.ac.kr
}

Accepted 8 June 2005

Abbreviation: mblL-2, membrane-bound form of IL-2

\begin{abstract}
Transduction of cytokine gene into tumor cells is a promising method of tumor therapy, but the value is limited by accompanying side effects. To focus antitumor immune response to tumor antigen-specific CTL, we developed an antitumor vaccine by transfecting modified IL-2 gene in a membrane-bound form (mbIL-2) into B16F10 melanoma cells. The mblL-2 clone showed reduced tumorigenicity and metastatic ability, and inhibited metastasis and prolonged the survival of mice against B16F10 cells. The inhibition of B16F10 metastasis by mblL-2 was accompanied by the increment of $C D 8^{+} \mathrm{T}$ cells. The metastasis of $\mathrm{mblL}-2$ clone was significantly increased in the $\mathrm{CD} 8^{+} \mathrm{T}$ cell-depleted mice, but not in $\mathrm{CD} 4^{+} \mathrm{T}$ cell depleted mice. Spleen cells immunized with the mblL-2 clone showed higher CTL activity towards B16F10 cells than those immunized with control cells. The size of $\operatorname{CD} 8^{+} T$ cell population in the lung of mice injected with the mblL-2 clone was markedly greater than that of mice injected with B16F10 cells, but there was no detectible change in $\mathrm{CD}^{+}$and $\mathrm{CD}^{+} \mathrm{T}$ cell populations of lymph nodes and spleen. These results suggest that when the mblL-2 clone is introduced into the blood stream, it migrates mainly to lung and activates $C D 8^{+} \mathrm{T}$ cells in situ, possibly by direct priming. Such a tumor vaccine may ameliorate the toxic side effects encountered with conventional cytokine gene therapy.
\end{abstract}

Keywords: cancer vaccines; immunotherapy, active; interleukin-2; neoplasm metastasis; T lymphocytes, cytotoxic

\section{Introduction}

Several strategies employing cytokines to enhance host immunity have been developed for use in experimental cancer therapy. Recombinant IL-2 is usually applied systemically and therapeutic effects generally are often accompanied by severe toxic side effects (Lotze MT et al., 1986; Kammula et al., 1998; Chen et al., 2001; Yang et al., 2003). The transfer of IL-2 gene into tumor cells has the advantage that it can achieve local activation of the immune system at the tumor site (Fearon et al., 1990; Gansbacher et al., 1990; Becker et al., 1996; Jackaman et al., 2003; Hillman et al., 2004).

A large number of different cytokines have been shown to stimulate anti-tumor immunity in studies employing tumor cells transduced with cytokine genes as therapeutic vaccines (Blankenstein et al., 1991; Dranoff et al., 1993; 1995; Tepper et al., 1994; Nanni et al., 1999). Even tumors that are poorly immunogenic can be recognized by MHC class I-restricted $\mathrm{CD}^{+}$cytotoxic $\mathrm{T}$ cells, if the tumor cells are engineered to harbor the IL-2 gene. However, tumor cells engineered to produce cytokines have unexpected side effects (Dranoff et al., 1993; Lollini et al., 1995; Tjuvajev et al., 1995) that may be caused by activation of bystander $T$ cells, or differentiation and expansion of $\mathrm{T}$ cells, without evident specificity for the tumor antigen (Rivoltini et al., 1990; Colombo et al., 1992). Control of the effective range, dosage, and duration of cytokines may be critical for successful cytokine gene therapy.

Several cytokines, including IL-1 (Kurt-Jones et al., 1987), TNF $\alpha$ (Kriegler et al., 1988), LT $\alpha$ (Browning et al., 1993) and IFN- $\gamma$ (Assenmacher et al., 1996) are expressed as membrane-associated forms and soluble forms. Though functional differentiation between membrane-bound and soluble forms has not been clearly demonstrated, the effective range of membrane-bound form may well be narrower. Interestingly, genetically engineered membrane-bound form of TNF $\alpha$ on tumor cells induced anti-tumor immunity with low toxic side effect (Marr et al., 1997). Such modification of cytokine gene therapy adopting membrane-bound form has been expanded to GM-CSF (el-Shami et al., 1999; Soo Hoo et al.,1999; Yei et al., 2002), FLt3 ligand (Chen et al., 1997), IL-4 (Kim et al., 2000), and IL-12 (Cimino et al., 2004). Furthermore, anchoring of IL-2 via diphtheria toxin T domain on tumor cells induced successful anticancer immunity 
(Nizard et al., 2003).

In the present study, we modified B16F10 cells to express a membrane-bound form of IL-2 (mblL-2), and tested tumorigenicity and metastatic ability and therapeutic effects. We envisaged that if the tumor cells displayed the proper tumor-associated antigen/ MHC complex together with $\mathrm{IL}-2$, in a membranebound form, tumor antigen-specific CTL precursors might be selectively activated, so minimizing side effects. Moreover, the expression of IL-2 on tumor cells might compensate the reduced function of Th cells observed in most tumor-bearing mice (Zier et al., 1996).

\section{Materials and Methods}

\section{Cells and animals}

The murine melanoma B16F10 cell line was cultured in RPMI-1640 supplemented with $2 \mathrm{mM}$ L-glutamine, $100 \mathrm{U} / \mathrm{ml}$ penicillin, $100 \mu \mathrm{g} / \mathrm{ml}$ streptomycin, and $10 \%$ heat-inactivated fetal bovine serum (all from Sigma Chemical Co., St. Louis, MI). The tumor cell line maintained regular in vivo passages to preserve tumorigenicity and metastatic ability. The B16F10 cells were used for experiments while in the log phase of growth. CTLL-2 cells were maintained in the same medium extra-supplemented with $10 \mathrm{U} / \mathrm{ml} \mathrm{IL-2} \mathrm{(R \& D}$ Systems Inc., Minneapolis, MN). GK1.5 (anti-CD4) and 3.168 (anti-CD8) were given as subcutaneous injection of $1 \times 10^{6}$ cells/mouse on day $-1,+3,+7$ prior to $3-2 \mathrm{E} 5$ clone injection. Depletion of $\mathrm{T}$ cell subsets was confirmed by FACS analysis using anti-CD4 (L3T4 clone) and anti-CD8 (Ly-2 clone) antibodies (Pharmingen, San Diego, CA). The female C57BL/6 mice were purchased from the Orient company (Gapeung, Korea) and used at 6-8 weeks of age.

\section{Plasmid construction and transfection}

The cDNA of mouse IL-2 was purchased from American Type Culture Collection (Rockville, MD). The cDNA of mouse TNF $\alpha$ was obtained from Dr. SangYoung Chun (Chonnam National University, Korea). To construct mblL-2 chimeric CDNA, primers specific for IL-2 (sense; 5'-CGCGAATTCATGTACAGCATGCAGCTCGCA-3', antisense; 5'-GCGCCATGGTTGAGGGCTTGTTGAGATGAT-3') and TNF $\alpha$ (sense; 5'GCGGATCCATG-AGCACAGAA-3', antisense; 5'-CGCGAATTCCTCCGGCCATAGAACT-3') were used to amplify the respective cDNA fragments. The $525 \mathrm{bp}$ IL-2 cDNA fragment was digested with Hincll/BamHI to exclude IL-2 signal peptide region. The $240 \mathrm{bp}$ TNF $\alpha$ cDNA fragment encoding transmembrane region (from -79 to -45 ), cytoplasmic part (from 44 to -24 ), and 19 extracellular amino acids (from -23 to -5) was ligated to the $525 \mathrm{bp} \mathrm{IL-2}$ cDNA fragment. The chimeric cDNA was then subcloned in pNeoSRoll expression vector.

For electroporation, B16F10 cells were harvested and washed twice in HBSS (137 mM NaCl, $5 \mathrm{mM}$
$\mathrm{KCl}, 0.7 \mathrm{mM} \mathrm{H}_{3} \mathrm{PO}_{4}, 6 \mathrm{mM}$ dextrose, $20 \mathrm{mM}$ HEPES, $\mathrm{pH} 7.0)$. The cells $\left(5 \times 10^{6}\right.$ cells $)$ were resuspended in HBSS and mixed with $20 \mu \mathrm{g}$ of linearized plasmid DNA. After incubation on ice for $10 \mathrm{~min}$, they were electroporated at $280 \mathrm{~V}, 975 \mu \mathrm{F}$ (BioRad, Hercules, $\mathrm{CA})$ and transferred to normal medium. After $48 \mathrm{~h}$, cells were plated in 96-well plates in G418 (1 g/l) containing medium. The drug-resistant colonies were usually visible after 2-3 weeks.

\section{Measurement of mblL-2 expression}

Cells were first incubated for $30 \mathrm{~min}$ at $4^{\circ} \mathrm{C}$ with antiIL-2 mAb (S4.B6.34) appropriately diluted in staining buffer $(1 \times$ PBS containing $0.02 \%$ sodium azide and $2 \%$ FBS). Cells were then washed with staining buffer three times and incubated for an additional $30 \mathrm{~min}$ at $4^{\circ} \mathrm{C}$ with PE-goat anti-rat IgG antibody. The stained cells were analyzed on a FACSCalibur flow cytometer (Becton Dickinson, San Jose, CA).

\section{Assay of IL-2 activity}

Biological IL-2 activity of mblL-2 on tumor cells was measured by using the CTLL-2 cells as described previously. Briefly, the CTLL-2 cells were harvested and washed three times with medium. The X-ray irradiated mblL-2 tumor cells (200 Gy) were mixed with CTLL-2 cells in a final volume of $200 \mu$ using flat-bottomed 96-well plates. As positive control, recombinant $\mathrm{IL}-2 \quad(0.016 \mathrm{U} / \mathrm{ml})$ was supplied. The cultures were incubated for $72 \mathrm{~h}$ at $37^{\circ} \mathrm{C}$, pulsed for the final $16 \mathrm{~h}$ with $0.5 \mu \mathrm{Ci}$ of $\left[{ }^{3} \mathrm{H}\right.$ ]thymidine (Amersham, Piscataway, NJ) per well, and samples were collected using a PHD cell harvestor (Skatron, Norway). $\left[{ }^{3} \mathrm{H}\right]$ thymidine incorporation was used as an index of DNA synthesis with results expressed as mean cpm per culture.

\section{Tumor challenge}

For tumorigenicity studies, mice were inoculated subcutaneously on the neck or intraperitoneally with $1 \times$ $10^{5}$ live cells, and tumor growth was measured daily. Tumor size was estimated by measuring the longest surface diameter using a caliper. In the metastasis studies, cells were injected intravenously $\left(2.5 \times 10^{5}\right.$ live cells per mouse) through lateral tail vein. After 2 weeks, mice were sacrificed and black tumornodules established on lung were counted. For therapeutic effect studies, X-ray irradiated (200 Gy) tumor cells were mixed with live wild type B16F10 cells, and co-injected subcutaneously. Inoculated mice were monitored daily, and the mice were killed when they became moribund.

For inhibition effect of metastasis, X-ray irradiated (200 Gy) tumor cells $\left(5 \times 10^{6}\right.$ per mouse) were mixed with live wild type B16F10 cells $\left(5 \times 10^{4}\right.$ per mouse) and co-injected intravenously through lateral tail vein. After 12 days, mice were sacrificed and black tumor-nodules established on lung were counted. 


\section{In vivo $\mathrm{T}$ cell depletion}

To deplete $\mathrm{CD} 4^{+}$or $\mathrm{CD} 8^{+} \mathrm{T}$ cells, GK1.5 hybridoma cells $\left(1 \times 10^{6}\right.$ cells/mouse) for $\mathrm{CD}^{+} \mathrm{T}$ cell depletion and 3.168 hybridoma cells $\left(1 \times 10^{6}\right.$ cells/mouse $)$ for $\mathrm{CD}^{+}{ }^{+} \mathrm{T}$ cell depletion were injected into $\mathrm{C} 57 \mathrm{BL} / 6$ mice subcutaneously three times with 4 days interval, respectively. Depletion of the $\mathrm{CD}^{+} \mathrm{T}$ cells or $\mathrm{CD} 8^{+}$ $T$ cells was confirmed by FACS analysis of peripheral blood cells of the mice.

\section{CTL assay}

The immunized spleen cells were assessed for their cytolytic activity against B16F10 cells in triplicate in $4 \mathrm{~h}{ }^{51} \mathrm{Cr}$-release assays. To prepare effector cells, splenocytes were prepared from mice 2 weeks after the second immunization with X-ray irradiated $(200$ Gy) tumor cells. The splenocytes $\left(1 \times 10^{7}\right.$ cells) were cultured with $6.5 \times 10^{5}$ MMC-treated tumor cells as stimulator in $5 \mathrm{ml}$ RPMI-1640 medium. After 4 days, live cells were counted and resuspended at the desired concentration for CTL assay. Target cells were labeled with $100 \mu \mathrm{Ci}$ of $\mathrm{Na}_{2}{ }^{51} \mathrm{CrO}_{4}$ (New England Nuclear-DuPont, Bedford, MA) and suspended at a concentration of $1 \times 10^{4}$ cells per $100 \mu \mathrm{l}$ in roundbottomed 96 -well plates. Various numbers of effector cells suspended in $100 \mu$ assay medium were then added to each well. After $4 \mathrm{~h}$ incubation and brief centrifugation, $100 \mu \mathrm{l}$ of supernatant were collected from each well and counted in an automated gammacounter. The percent specific ${ }^{51} \mathrm{Cr}$ release was determined using following formula: $\left(\mathrm{cpm}_{\text {experimental release }}\right.$ - $\left.\quad c p m_{\text {spontaneous release }}\right) \times 100 /\left(c p m_{\text {maximum }}\right.$ release -

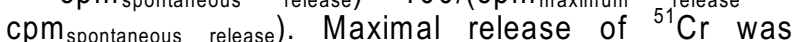
obtained by lysis of target cells with $2 \%$ Triton-X 100. Spontaneous ${ }^{51} \mathrm{Cr}$ release was measured by incubating target cells in the absence of effector cells and was less than $20 \%$ of maximum release.

\section{Preparation of cell suspensions from organs}

C57BL/6 mice splenocytes were prepared using a standard protocol. Briefly, mice were killed by cervical dislocation, and splenocytes were prepared by mechanical disruption. Lung tissues were digested three times by shaking for $30 \mathrm{~min}$ at $37^{\circ} \mathrm{C}$ in RPMI-1640 medium containing $1 \mathrm{mg} / \mathrm{ml}$ collagenase VII (SigmaAldrich, St. Louis, Missouri) and 2\% FBS (Hyclone, Logan, UT). Lung cells were passed through a $70 \mu \mathrm{m}$ nylon filter (Becton Dickinson, Franklin Lakes, NJ), erythrocytes were lysed with an ammonium chloride potassium lysis buffer, and the total number of cells was enumerated by trypan blue exclusion.

\section{Immunohistochemistry}

Infiltration of $\mathrm{CD}^{+} \mathrm{T}$ cells and $\mathrm{CD}^{+} \mathrm{T}$ cells in lung was assayed by immunohistochemistry. Immunohistochemistry was performed using a Chemmate EnVision Detection Kit (DAKO, Carpinteria, California). Paraffin sections of lung were de-waxed and re-hydrated, washed three times with phosphate-buffered saline, and treated with proteinase $\mathrm{K}$ (DAKO ready to use kit) for $5 \mathrm{~min}$ at $37^{\circ} \mathrm{C}$ and followed by the DAKO LSAV 2 System peroxidase kit instruction. Briefly, tissue sections were washed with PBS $/ 0.1 \%$ Tween 20 and treated with $\mathrm{H}_{2} \mathrm{O}_{2}$ for $10 \mathrm{~min}$ at room temperature, blocked in PBS $/ 0.1 \%$ Tween $20 / 1 \%$ BSA for $20 \mathrm{~min}$ at room temperature. The tissue sections were washed three times with PBS $/ 0.1 \%$ Tween 20, and followed by anti-mouse CD4 and CD8 antibodies (1:200 dilutions) for $30 \mathrm{~min}$ at room temperature. After incubation with secondary antibody for $30 \mathrm{~min}$ at RT, tissue sections were counter stained with hematoxylin and mounted. Immunostaining was visualized and pictured by a microscope. Sections without primary antibody were used as negative control.

\section{Results}

Stable expression of mblL-2 on tumor cell surface

We transfected B16F10 cells with the pNeoSR $\alpha$ ll vector harboring the neomycin-resistance gene and a chimeric IL-2 cDNA made up of cDNAs encoding the extracellular domain of IL-2 and the transmembrane domain of $T N F \alpha$, a type II transmembrane protein (Figure 1A). The transfectants were selected with G418 and the expression of $\mathrm{mblL}-2$ in the transfectants was analyzed with FACS using IL-2 specific S4.B6.34 mAb (Figure 1B). Clone 3-2E5 was selected for further study from 7 clones carrying mblL-2. It expressed IL-2 stably on cell surface, and growth rate in culture was indistinguishable from the parental B16F10 cells and vector-transduced clone. We also tested the biological effectiveness of mblL-2 on the tumor cells by setting up a mixed cell culture with CTLL-2 cells, an IL-2 dependent cell line. X-ray irradiated mblL-2 tumor cells supported proliferation of the CTLL-2 cells, whereas the B16F10 cells did not (Figure 1C). This result indicates that the mblL-2 on tumor cells has biological function of IL-2.

\section{Reduced tumorigenicity of mblL-2 clone}

To analyze the effect of mblL-2 expression on tumorigenicity, B16F10 cells, vector-transduced cells, and mblL-2 cells were injected subcutaneously into syngeneic C57BL/6 mice, and tumor growth was monitored. Tumor growth of mblL-2 clone was much delayed compared to the other two groups of tumor cells (Figure 2A). However, the growth rate of the mblL-2 tumors, once tumor growth started, was similar to those by other tumor cells. We also studied the tumorigenicity of the mblL-2 cells by intraperitoneal injection. Mice injected with mblL-2 cells survived much longer than those injected with two types of control cells (Figure 2B). All the latter died within 42 days, whereas 4 of 10 mice injected with mblL-2 cells survived for more than 2 months. This indicates that expression of IL-2 in a membrane-bound form increases the immunogenicity of the tumor cells. 
A

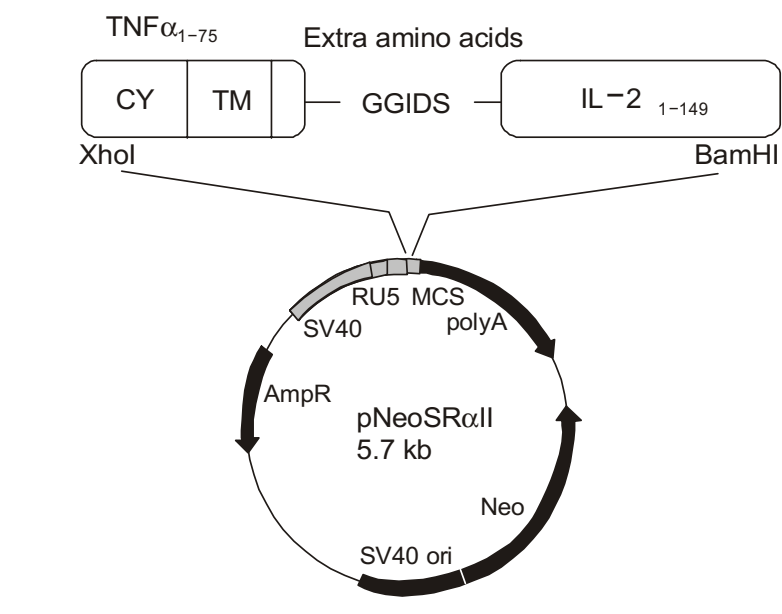

C

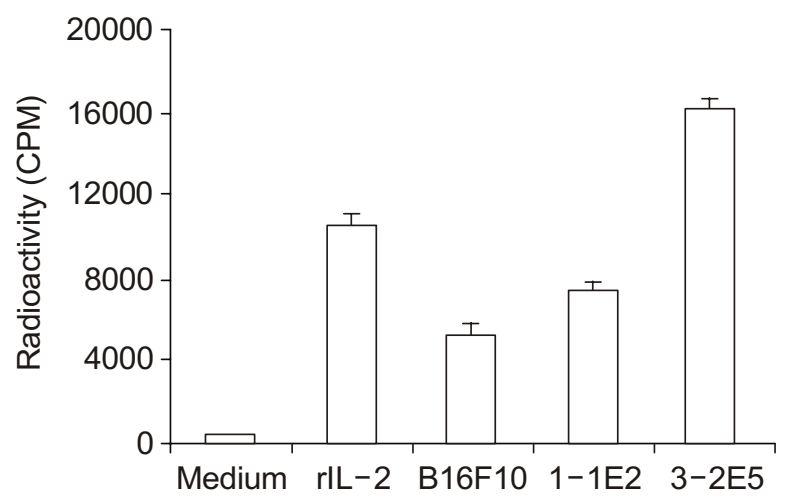

B
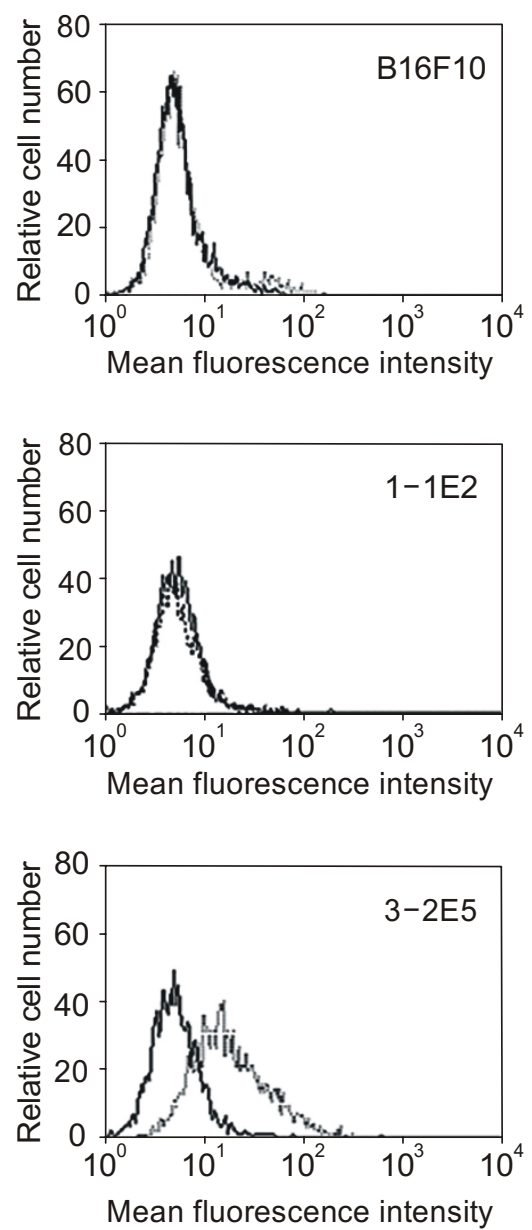

Figure 1. Structure and expression of the mblL-2 chimera. (A) The fusion gene carried by mbIL-2 is composed of TNF $\alpha$ (56 amino acids encompassing the cytoplasmic, transmembrane, and 19 extracellular amino acids), and five spacer amino acids (GGIDS), and IL-2 coding sequences (from 1 to 149 amino acids without signal peptide). The chimeric cDNA was subcloned into the pNeoSR $\alpha$ ll vector with G418 selection marker. (B) Surface expression of chimeric mblL-2 on transfected B16F10 cells. B16F10 cells, 1-1E2, and mblL-2 clone were stained with monoclonal antibody to IL-2 (S4.B6.34) and followed by PE-conjugated goat anti-rat IgG antibody. (C) Proliferation of CTLL-2 in response to mbIL-2 clone. CTLL-2 cells were plated at 20,000 cells per well in flat bottomed 96-well plate and cultured with irradiated B16F10, 1-1E2, and $3-2 \mathrm{E} 5$ cells $(10,000$ cells per well) for $72 \mathrm{~h}$, respectively. As a control, CTLL-2 cells were treated with final concentration of $0.016 \mathrm{U} / \mathrm{ml}$ recombinant IL-2. Proliferation of CTLL-2 was measured by incorporation of $\left.{ }^{3} \mathrm{H}\right]$ thymidine for last $16 \mathrm{~h}$ in the incubation.

To analyze the therapeutic effect of $\mathrm{mblL}-2$ cells, mice were injected with wild type B16F10 cells mixed with X-ray irradiated mblL-2 cells (or control cells). All mice co-injected with irradiated B16F10 cells or vector-transduced cells died within 27 days, whereas the mice co-injected with inactivated mblL-2 cells survived longer (Figure $2 \mathrm{C}$ ). Though protection was not complete in this study, possibly because of reduced expression of MHC class I molecules on the B16F10 cells, we were able to detect a small therapeutic effect of the mblL-2 cells.

\section{Reduced metastatic ability of mblL-2 clone}

To analyze the ability of mblL-2 cells to spread to intravascular locations in the lung, $2.5 \times 10^{5}$ cells of each type were injected through the tail vein into C57BL/6 mice. After two weeks, all the mice were killed and the black metastasis nodules in their lung were counted. Lung of the mice injected with mblL-2 cells contained much fewer metastatic nodules than the mice injected with the control cells (Figure $3 \mathrm{~A}$ ). Thus expression of mblL-2 on tumor cells reduced their metastatic ability. This outcome suggests that the mblL-2 cells introduced into the blood stream may efficiently activate immune cells in the draining lymph 
A
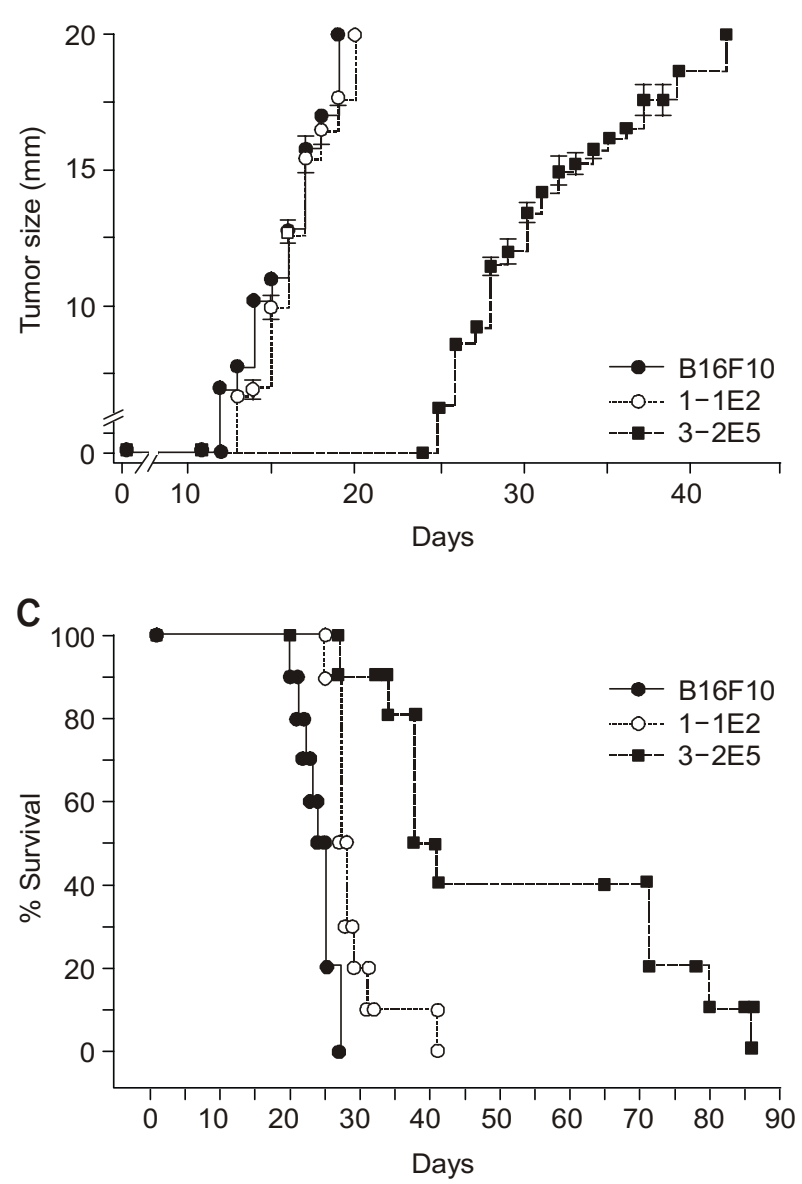

nodes, or that tumor cells that have metastasized to the lung may activate immune cells in situ.

To examine which $\mathrm{T}$ cell subpopulation is responsible for the low metastatic ability of mblL-2 clone, $\mathrm{CD}^{+} \mathrm{T}$ cell depleted and $\mathrm{CD} 8^{+} \mathrm{T}$ cell depleted mice were challenged with $3-2 E 5$ clone. First of all, depletion of $\mathrm{CD}^{+}$and $\mathrm{CD}^{+} \mathrm{T}$ cell subpopulations in peripheral bloods was confirmed on day 1 , and 4 after hybridoma cell injections (Figure 3B). Interestingly, the number of black nodules formed by $3-2 E 5$ clone was significantly increased in $\mathrm{CD}^{+} \mathrm{T}^{\mathrm{T}}$ cell depleted mice, but not in the $\mathrm{CD}^{+} \mathrm{T}$ cell depleted mice (Figure $3 \mathrm{C}$ ). The results suggest that $C D 8^{+} \mathrm{T}$ cells are responsible for the reduced metastatic ability of $3-2 E 5$ clone.

To analyze the immunogenicity in terms of metastasis inhibition, mice were injected intravenously with wild type B16F10 cells mixed with $\mathrm{X}$-ray inactivated $\mathrm{mblL}-2$ clone. The mice co-injected with mblL-2 clone had much fewer metastatic nodules in lung and contained prominently increased number of $\mathrm{CD}^{+} \mathrm{T}$ cells than those co-injected with $\mathrm{X}$-ray inactivated $\mathrm{B} 16 \mathrm{~F} 10$ cells (Figure 4A, 4B). This effect may result from the higher immunogenicity of mblL-2 cells.

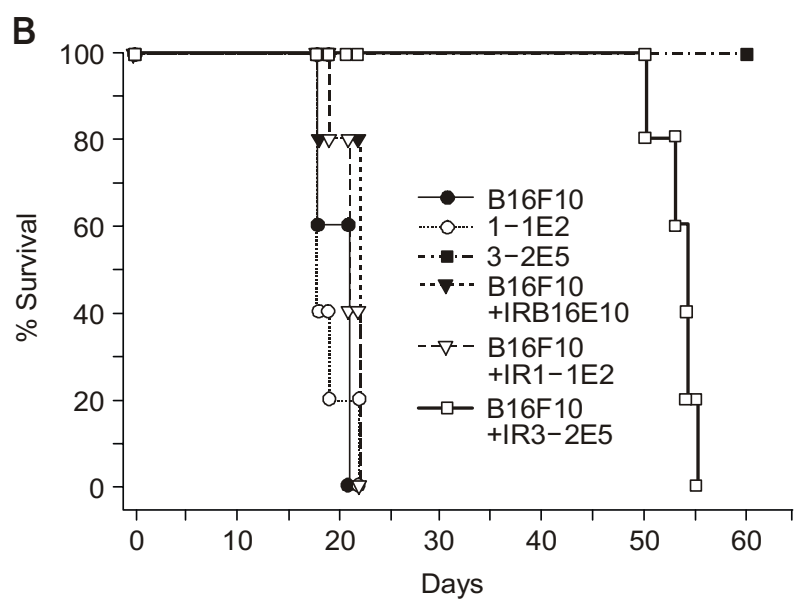

Figure 2. Tumor growth and survival curve in mice injected with mbIL-2 clone. (A) C57BL/6 mice ( $n=5$ per group) were injected subcutaneously with $1 \times 10^{5}$ cells of B16F10, 1-1E2 (vector control), and 3-2E5 (mbIL-2 clone). Diameters of the growing tumors were determined by measuring with caliper every day. (B) C57BL/6 mice ( $n=10$ per group) were injected intraperitoneally with live cells $\left(1 \times 10^{5}\right.$ cells $)$ of wild type B16F10 cells, vector transduced clone, and mblL-2 clone, respectively, and monitored everyday. (C) Therapeutic effect of mblL-2 clone. C57BL/6 mice ( $n=5$ per group) were subcutaneously injected with live B16F10 cells $\left(1 \times 10^{4}\right.$ cells per mouse) mixed with $5 \times 10^{6}$ cells of X-ray irradiated (200 Gy) B16F10, 1-1E2 vector clone, and 3-2E5 mblL-2 clone, respectively. The survival was monitored everyday.

\section{Induction of CTL activity by mblL-2 clone}

The therapeutic effect of mblL-2 cells led us to analyze their ability to induce CTL activity against B16F10 cells. Seven days after the second intraperitoneal immunization, splenocytes were prepared and stimulated in vitro for 4 days with $X$-ray irradiated mbIL-2 cells. Thereafter, ${ }^{51} \mathrm{Cr}$-labeled B16F10 target cells were added at various effector-to-target ratios for $4 \mathrm{~h}$, and significantly higher anti-B16F10 CTL activity was detected in the group stimulated with $\mathrm{mblL}-2$ cells (Figure 5). This result suggests that the therapeutic effect of mblL-2 cells is partly due to their superior CTL induction activity.

\section{Increase of $\mathrm{CDB}^{+} \mathrm{T}$ cells in the lung of the mice injected with mbIL-2 clone}

To identify the immune cells responsible for the therapeutic effect and the reduced metastatic ability of the mblL-2 cells, we analyzed the $\mathrm{CD} 4^{+}$and $\mathrm{CD} 8^{+}$ $T$ cell subpopulations of the lung, spleen and lymph nodes, two weeks after the intravenous injection of mblL-2 cells. Increased numbers of $\mathrm{CD}^{+} \mathrm{T}$ cells were detected only in the lung of mice injected with mblL-2 cells (Table 1). Interestingly enough, there was no 
A

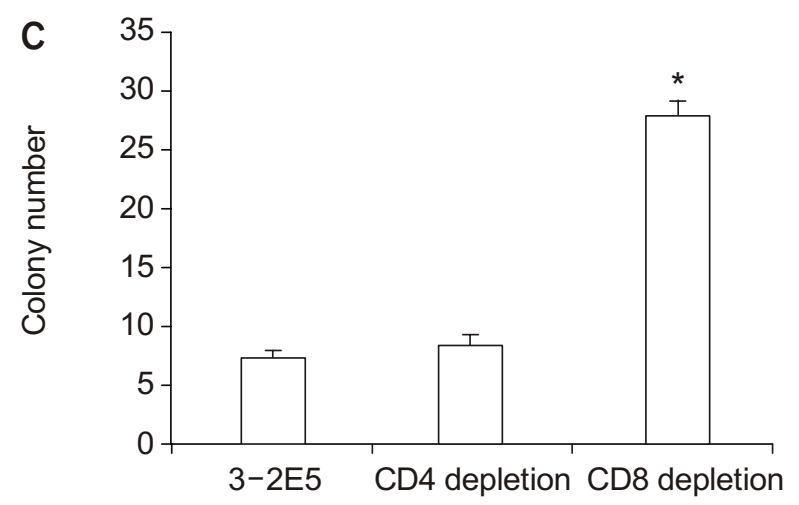

B
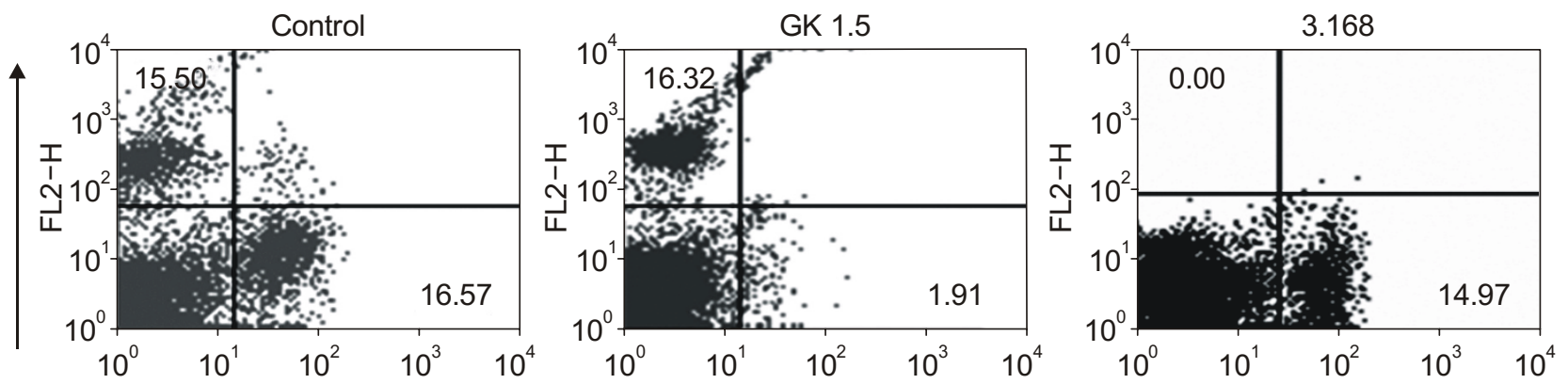

CD8

$\mathrm{FL} 1-\mathrm{H}$

$\mathrm{FL} 1-\mathrm{H}$

$\mathrm{FL} 1-\mathrm{H}$

CD4

Figure 3. Comparison of metastatic ability. (A) C57BL/6 mice were injected with mblL-2 clone $\left(2.5 \times 10^{5}\right.$ cells per mouse intravenously) through tail vein, and executed on $14^{\text {th }}$ day. The black metastatic nodules were counted with naked eyes. The experiment was repeated three times and the data presented as mean $\pm \mathrm{SE}$. (B) The percentage of $\mathrm{CD} 4^{+} \mathrm{T}$ cells and $\mathrm{CD} 8^{+} \mathrm{T}$ cells in peripheral blood cells were determined 4 days after subcutaneous injection GK1.5 hybridoma and 3.168 hybridoma $\left(1 \times 10^{6}\right.$ cells/mouse). 3-2E5 cells $\left(1 \times 10^{6}\right.$ cells/mouse $)$ were injected subcutaneously as control. (C) To deplete the $\mathrm{CD} 4^{+} \mathrm{T}$ cells or $\mathrm{CD} 8^{+} \mathrm{T}$ cells subpopulation, C57BL/6 mice were injected with GK1.5 hybridoma cells or 3.168 hybridoma cells subcutaneously three times with 4 days interval, respectively. After $24 \mathrm{~h}$ of final injection, mice were challenged with $3-2 \mathrm{E} 5$ cells $1 \times 10^{6}$ intravenously. After 10 days, mice were sacrificed, and the black metastatic nodules in lung were counted. The experiment was repeated at least 3 times and a representative result was presented (2 mice per group). ${ }^{* \star} P<0.05$ compared to B16F10 group (A), and ${ }^{*} P<0.01$ compared with $3-2 \mathrm{E} 5$ group $(\mathrm{C})$.

significant change in the $\mathrm{CD} 4^{+} \mathrm{T}$ cell population in the lung. There was no significant change in $\mathrm{CD4}^{+}$ and $\mathrm{CDB}^{+} \mathrm{T}$ cell populations of the lymph nodes and spleen. These results suggest that the mblL-2 cells migrate into lung and activate selectively $\mathrm{CD} 8^{+} \mathrm{T}$ cells in situ, possibly by the direct priming mode.

\section{Discussion}

In most experimental approaches to cytokine gene tumor therapy, different effector cells are involved, depending on the type of cytokine and the origin of tumor (Blankenstein et al., 1991; Colombo et al., 1992; Dranoff et al., 1993; Tepper et al., 1994; Dranoff et al., 1995; Nanni et al., 1999). GM-CSFtransduced tumor cells activated dendritic cells and led to activation of CTL as well as Th cells (Dranoff et al., 1993). Tumor cells transduced with IL-2 gene activated CTL effectively in various tumor models (Fearon et al., 1990; Gansbacher et al., 1990; Blankenstein et al., 1991; Becker et al., 1996; Jackaman et al., 2003; Hillman et al., 2004). Though there have been many positive results with cytokine gene transfer approach for tumor therapy, unexpected side effects became obstacles. More thorough in vivo studies in animal system revealed that the cells infiltrated the tumor injection sites were heterogeneous and only a limited numbers of CTL were specific for the tumor antigens (Rivoltini et al., 1990; Colombo et al., 1992). The activated Th cells may secrete a variety of cytokines and cause massive immune cell activation not relevant to tumor antigens. The effective rage of cytokine and non-specific activation of immune cells may contribute to the side effects.

To focus anti-tumor immunity on tumor antigenspecific CTL, we developed a strategy based on di- 
A

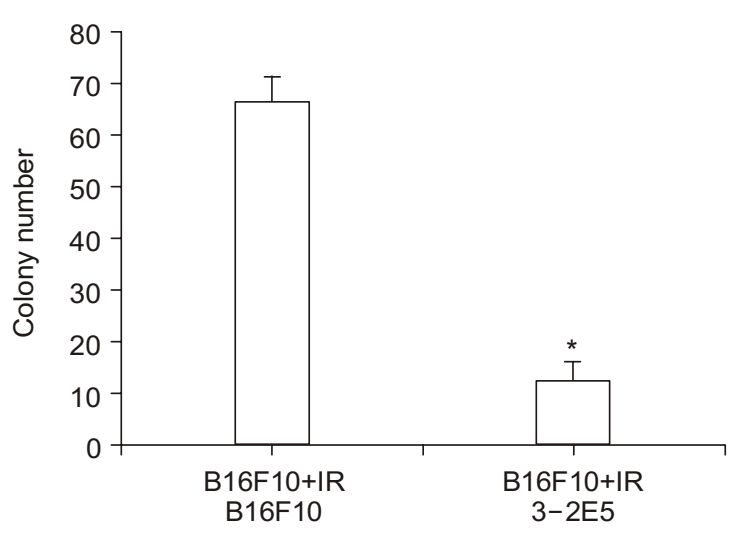

B

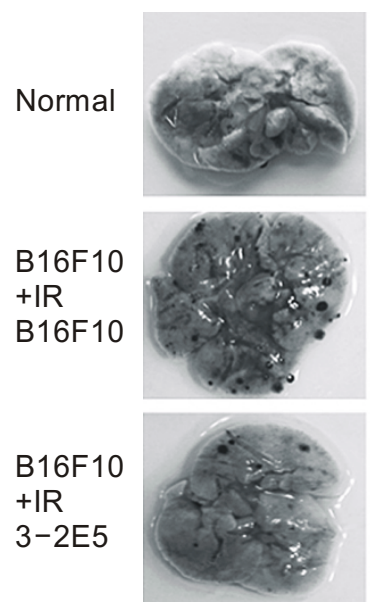

CD4

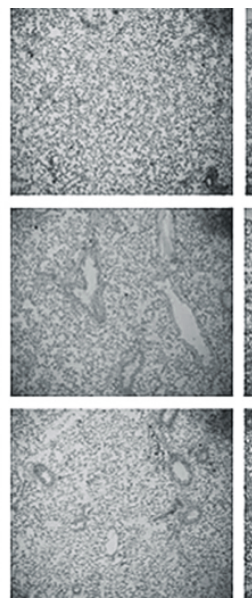

CD8
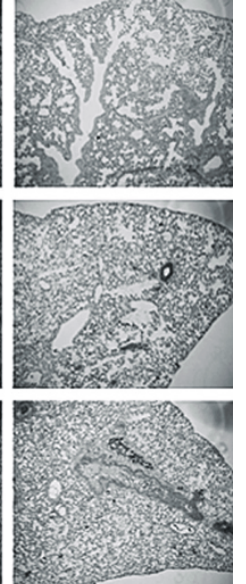

Figure 4. Inhibition of metastasis by mblL-2 clone. (A) C57BL/6 mice ( $n=5$ per group) were injected intravenously with live B16F10 cells $(5$ $\times 10^{4}$ cells per mouse) mixed with $5 \times 10^{6}$ cells of X-ray irradiated (200 Gy) B16F10 and 3-2E5 mblL-2 clone, and executed on $12^{\text {th }}$ day. ${ }^{*} P<0.01$ compared with B16F10 group. (B) Each lung paraffin sections was stained with anti-mouse CD4 antibody and anti-mouse CD8 antibodies. Immunostaining was visualized and pictured by a microscope.

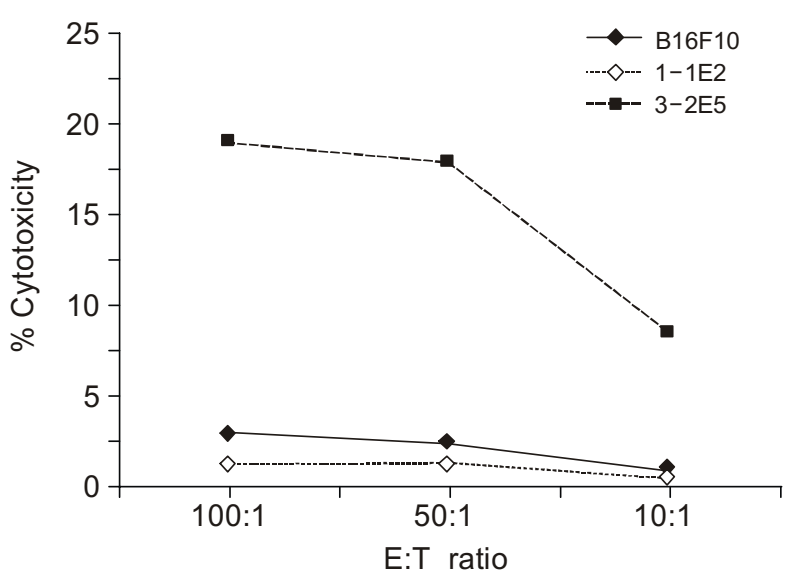

Figure 5. Induction of CTL activity by mblL-2 clone. Spleen cells were prepared from the mice in vivo immunized twice with $1 \times 10^{6}$ cells of the irradiated (200 Gy) B16F10 cells, 1-1E2 vector clone, and 3-2E5 mbIL-2 clone, respectively. Two weeks after the second immunization, the spleen cells $\left(1 \times 10^{7}\right.$ cells $)$ from each group of mice ( $n=3$ per group) were mixed-cultured with each corresponding stimulator cells $\left(6.5 \times 10^{5}\right.$ cells $)$ after MMC-inactivation. After 4 days, the effector cells were harvested and ${ }^{51} \mathrm{Cr}$-labeled B16F10 cells were used as target for the CTL assay.

rect priming. Several evidences for direct priming of CTL have been already reported (Wang et al., 1995; Wolkers et al., 2001). Expression of co-stimulatory molecules on tumor cells also provides strong signal for CTL activation (Huang et al., 1994; Bai et al., 2001; Vesosky et al., 2003). These results indicate that the tumor cells contact physically to CTL precursors and the co-stimulatory molecules on tumor cells act on corresponding receptors on T cells. Tu-
Table 1. Change in the T cell subpopulations in the lung, spleen, and lymph node after mblL-2 clone injection.

\begin{tabular}{|c|c|c|c|c|}
\hline $\mathrm{T}$ cell & population & $\mathrm{B} 16 \mathrm{~F} 10$ & $1-1 \mathrm{E} 2$ & $3-2 \mathrm{E} 5$ \\
\hline \multirow{2}{*}{ Lung } & $\mathrm{CD}^{+}{ }^{+} \mathrm{T}$ cell & 17.79 & 15.06 & 15.25 \\
\hline & $\mathrm{CD8}^{+} \mathrm{T}$ cell & 23.57 & 20.51 & 34.52 \\
\hline \multirow{2}{*}{ Spleen } & $\mathrm{CD}^{+}{ }^{+} \mathrm{T}$ cell & 14.63 & 19.26 & 16.07 \\
\hline & $\mathrm{CD8}^{+} \mathrm{T}$ cell & 13.34 & 15.80 & 14.83 \\
\hline \multirow{2}{*}{$\begin{array}{l}\text { Lymph } \\
\text { node }\end{array}$} & $\mathrm{CD}^{+} \mathrm{T}$ cell & 19.00 & 19.21 & 21.00 \\
\hline & $\mathrm{CD}^{+} \mathrm{T}$ cell & 26.22 & 25.91 & 27.48 \\
\hline
\end{tabular}

C57BL/6 mice were injected with $1 \times 105$ cells of B16F10, $1-1 \mathrm{E} 2$ (vector) and 3-2E5 (mblL-2) cells intravenously. After two weeks, cell suspensions from lung, spleen and lymph node were prepared and stained with FITC-conjugated anti-mouse CD4 mAb and PE-conjugated anti-mouse CD8 mAb.

mor cells engineered to express membrane-bound form of TNF $\alpha$ induced antitumor effect with lower toxic side effect compared with those expressing secretory form of TNF $\alpha$ (Marr et al., 1997). GM-CSF (el-Shami et al., 1999; Soo Hoo et al., 1999; Yei et al., 2002) and Flt3 ligand (Chen et al., 1997) were also engineered to be expressed as membrane-bound forms on tumor cells with intention to prepare potent stimulators for antigen presenting cells. The tumor cells expressing GPI-anchored IL-12 induced antitumor immunity comparable to the effects of secretory IL-12 (Cimino et al., 2004). Nizard group developed anticancer vaccine anchoring recombinant IL-2 via diphtheria toxin $\mathrm{T}$ domain to avoid using viral vectors, which may cause toxic side effects (Nizard et al., 2003). The membrane-anchored IL-2 on tumor cells 
induced tumor specific CTL activity. These all suggest that membrane-bound form of cytokines acts on target cells by cell-to-cell contact.

In a previous study, we reported that the tumor cells expressing IL-4 in membrane-bound forms lost tumorigenicity and induced systemic anti-tumor immunity (Kim et al., 2000). These cells were effective in activating $\mathrm{CD}^{+} \mathrm{T}$ cells without noticeable effect on $\mathrm{CD}^{+} \mathrm{T}$ cells. In this study, we expanded our observations, by introducing IL-2 gene in a membrane-bound form into the spontaneous metastatic tumor cell line, B16F10 cells. Expression of mblL-2 on tumor cells was effective in inducing CTL activity and in prolonging the survival of mice co-challenged with viable wild type B16F10 cells. Furthermore, the mblL-2 clone inhibited metastasis of B16F10 cells effectively. Though both mblL-2 and mblL-4 on tumor cells induced anti-tumor immunity in different tumor models respectively, the two cytokines would affect CTL precursors in different ways. It will be interesting to differentiate the effect of the cytokines on CTL precursors.

The induction of tumor-specific $T$ cell immunity is thought to involve two pathways. First, it is induced as a result of direct priming of naive $\mathrm{CD} 8^{+} \mathrm{T}$ cells by tumor cells that have migrated from the tumor injection site to the secondary lymphoid tissues (Wang et al., 1995). Second, the T cell response may result from cross-presentation of tumor cell-derived antigens by professional antigen presenting cells (Huang et al., 1994; Muller et al., 2001; van Mierlo GJ et al., 2004). Our results suggest that the mblL-2 cells mainly migrate into lung and stimulate $\operatorname{CD} 8^{+} \mathrm{T}$ cells by direct priming in situ, because there was no significant change in the number of $\mathrm{CD}^{+}$and $\mathrm{CD} 8^{+}$ $\mathrm{T}$ cells in the spleen and lymph nodes (Table 1). Alternatively, mblL-2 cells in the draining lymph nodes may activate CTL by direct priming and the CTL primed by mblL-2 cells may migrate to the tumorgrowing site, mainly to lung. Metastasis of breast cancer cells shares relevant similarities with leukocyte trafficking and seems to be mediated through CXCR4 or CCR7 signaling (Cardones et al., 2003). We also found that the mblL-2 increased the expression of CXCR4 on B16F10 cells, but not the ICAM-1 (data not shown). The lung was known to express SDF-1, a CXCR4 ligand, so that the mblL-2 clone might migrate to lung effectively.

On the basis of these in vivo and in vitro results, we propose that mblL-2 on tumor cells may act as a selective stimulatory molecule for the activation of tumor antigen-specific CD8 ${ }^{+} \mathrm{T}$ cells, possibly by direct priming. Our approach, expressing $\mathrm{IL}-2$ as a membrane-bound form on tumor cells would be an efficient way to focus antitumor immune responses to CTL in conventional cytokine gene therapy

\section{Acknowledgement}

This work was supported by the Korea Research Foundation Grant (KRF-2002-015-CP0303) and partially by a grant of the Korea Health 21 R\&D Project,
Ministry of Health and Welfare, Republic of Korea (01PJ4-PG4-01VN02-0063). The FACSCalibur in Chungnam National University has been maintained with a grant from the Korea Basic Science Institute since 2000.

\section{References}

Assenmacher M, Scheffold A, Schmitz J, Segura Checa JA, Miltenyi S, Radbruch A. Specific expression of surface interferon-gamma on interferon-gamma producing $T$ cells from mouse and man. Eur J Immunol 1996;26:263-7

Bai XF, Bender J, Liu J, Zhang H, Wang Y, Li O, Du P, Zheng $P$, Liu $Y$. Local costimulation reinvigorates tumorspecific cytolytic $T$ lymphocytes for experimental therapy in mice with large tumor burdens. J Immunol 2001;167:3936-43

Becker JC, Pancook JD, Gillies SD, Furukawa K, Reisfeld RA. T cell-mediated eradication of murine metastatic melanoma induced by targeted interleukin 2 therapy. J Exp Med 1996;183:2361-6

Blankenstein T, Rowley DA, Schreiber H. Cytokines and cancer: experimental systems. Curr Opin Immunol 1991;3: 694-8

Browning JL, Ngam-ek A, Lawton P, DeMarinis J, Tizard R, Chow EP, Hession C, O'Brine-Greco B, Foley SF, Ware CF. Lymphotoxin beta, a novel member of the TNF family that forms a heteromeric complex with lymphotoxin on the cell surface. Cell 1993;72:847-56

Cardones AR, Murakami T, Hwang ST. CXCR4 enhances adhesion of B16 tumor cells to endothelial cells in vitro and in vivo via beta(1) integrin. Cancer Res 2003;63:6751-7

Chen B, Timiryasova TM, Gridley DS, Andres ML, Dutta-Roy $\mathrm{R}$, Fodor I. Evaluation of cytokine toxicity induced by vaccinia virus-mediated IL-2 and IL-12 antitumour immunotherapy. Cytokine 2001;15:305-14

Chen K, Braun S, Lyman S, Fan Y, Traycoff CM, Wiebke EA, Gaddy J, Sledge G, Broxmeyer HE, Cornetta K. Antitumor activity and immunotherapeutic properties of Flt3 ligand in a murine breast cancer model. Cancer Res 1997;57: 3511-6

Cimino AM, Palaniswami P, Kim AC, Selvaraj P. Cancer vaccine development: protein transfer of membrane-anchored cytokines and immunostimulatory molecules. Immunol Res 2004;29:231-40

Colombo MP, Modesti A, Parmiani G, Forni G. Local cytokine availability elicits tumor rejection and systemic immunity through granulocyte-T-lymphocyte cross-talk. Cancer Res 1992;52:4853-7

Dranoff G, Jaffee E, Lazenby A, Golumbek P, Levitsky H, Brose $K$, Jackson V, Hamada $H$, Pardoll D, Mulligan RC. Vaccination with irradiated tumor cells engineered to secrete murine granulocyte-macrophage colony-stimulating factor stimulates potent, specific, and long-lasting anti-tumor immunity. Proc Natl Acad Sci USA 1993;90:3539-43

Dranoff $G$, Mulligan RC. Gene transfer as cancer therapy. Adv Immunol 1995;58:417-54 
el-Shami KM, Tzehoval E, Vadai E, Feldman M, Eisenbach L. Induction of antitumor immunity with modified autologous cells expressing membrane-bound murine cytokines. J Interferon Cytokine Res 1999;19:1391-401

Fearon ER, Pardoll DM, Itaya T, Golumbek P, Levitsky HI, Simons JW, Karasuyama H, Vogelstein B, Frost P. Interleukin-2 production by tumor cells bypasses $T$ helper function in the generation of an antitumor response. Cell 1990;60:397-4035

Gansbacher B, Zier K, Daniels B, Cronin K, Bannerji R, Gilboa E. Interleukin 2 gene transfer into tumor cells abrogates tumorigenicity and induces protective immunity. J Exp Med 1990;172:1217-24

Hillman GG, Slos P, Wang Y, Wright JL, Layer A, De Meyer $M$, Yudelev $M$, Che M, Forman JD. Tumor irradiation followed by intratumoral cytokine gene therapy for murine renal adenocarcinoma. Cancer Gene Ther 2004;11:61-72

Huang AY, Golumbek P, Ahmadzadeh M, Jaffee E, Pardoll $D$, Levitsky $H$. Role of bone marrow-derived cells in presenting MHC class I-restricted tumor antigens. Science 1994; 264:961-5

Jackaman C, Bundell CS, Kinnear BF, Smith AM, Filion P, van Hagen D, Robinson BW, Nelson DJ. IL-2 intratumoral immunotherapy enhances CD8+ T cells that mediate destruction of tumor cells and tumor-associated vasculature: a novel mechanism for IL-2. J Immunol 2003;171:5051-63

Kammula US, White DE, Rosenberg SA. Trends in the safety of high dose bolus interleukin-2 administration in patients with metastatic cancer. Cancer 1998;83:797-805

Kim YS, Sonn CH, Paik SG, Bothwell AL. Tumor cells expressing membrane-bound form of $\mathrm{IL}-4$ induce antitumor immunity. Gene Ther 2000;7:837-43

Kriegler M, Perez C, DeFay K, Albert I, Lu SD. A novel form of TNF/cachectin is a cell surface cytotoxic transmembrane protein: ramifications for the complex physiology of TNF. Cell 1988;53:45-53

Kundig TM, Bachmann MF, DiPaolo C, Simard JJ, Battegay M, Lother H, Gessner A, Kuhlcke K, Ohashi PS, Hengartner $H$. Fibroblasts as efficient antigen-presenting cells in lymphoid organs. Science 1995;268:1343-47

Kurt-Jones EA, Fiers W, Pober JS. Membrane interleukin 1 induction on human endothelial cells and dermal fibroblasts. J Immunol 1987;139:2317-24

Lollini PL, D'Errico A, De Giovanni C, Landuzzi L, Frabetti F, Nicoletti G, Cavallo F, Giovarelli M, Grigioni WF, Nanni $P$. Systemic effects of cytokines released by gene transduced tumor cells: marked hyperplasia induced in small bowel by gamma-interferon transfectants through host lymphocytes. Int J Cancer 1995;61:425-30

Lotze MT, Matory YL, Rayner AA, Ettinghausen SE, Vetto JT, Seipp CA, Rosenberg SA. Clinical effects and toxicity of interleukin-2 in patients with cancer. Cancer 1986;58:276472

Marr RA, Addison CL, Snider D, Muller WJ, Gauldie J, Graham FL. Tumour immunotherapy using an adenoviral vector expressing a membrane-bound mutant of murine TNF alpha. Gene Ther 1997:4:1181-8
Muller A, Homey B, Soto H, Ge N, Catron D, Buchanan ME, McClanahan T, Murphy E, Yuan W, Wagner SN, Barrera JL, Mohar A, Verastegui E, Zlotnik A. Involvement of chemokine receptors in breast cancer metastasis. Nature 2001;410:50-6

Nanni P, Forni G, Lollini PL. Cytokine gene therapy: hopes and pitfalls. Ann Oncol 1999;10:261-6

Nizard P, Gross DA, Babon A, Chenal A, Beaumelle B, Kosmatopoulos K, Gillet D. Anchoring cytokines to tumor cells for the preparation of anticancer vaccines without gene transfection in mice. J Immunother 2003;26:63-71

Ochsenbein AF, Sierro S, Odermatt B, Pericin M, Karrer U, Hermans J, Hemmi S, Hengartner H, Zinkernagel RM. Roles of tumour localization, second signals and cross priming in cytotoxic T-cell induction. Nature 2001;411:1058-64

Rivoltini L, Gambacorti-Passerini C, Squadrelli-Saraceno M, Grosso MI, Cantu G, Molinari R, Orazi A, Parmiani G. in vivo interleukin 2-induced activation of lymphokine-activated killer cells and tumor cytotoxic T-cells in cervical lymph nodes of patients with head and neck tumors. Cancer Res 1990;50:5551-7

Soo Hoo W, Lundeen KA, Kohrumel JR, Pham NL, Brostoff SW, Bartholomew RM, Carlo DJ. Tumor cell surface expression of granulocyte-macrophage colony-stimulating factor elicits antitumor immunity and protects from tumor challenge in the P815 mouse mastocytoma tumor model. J Immunol 1999;162:7343-49

Tepper RI, Mule JJ. Experimental and clinical studies of cytokine gene-modified tumor cells. Hum Gene Ther 1994; 5:153-64

Tjuvajev J, Gansbacher B, Desai R, Beattie B, Kaplitt M, Matei C, Koutcher J, Gilboa E, Blasberg R. RG-2 glioma growth attenuation and severe brain edema caused by local production of interleukin-2 and interferon-gamma. Cancer Res 1995;55:1902-10

van Mierlo GJ, Boonman ZF, Dumortier HM, den Boer AT, Fransen MF, Nouta J, van der Voort El, Offringa R, Toes $R E$, Melief CJ. Activation of dendritic cells that cross-present tumor-derived antigen licenses CD8+CTL to cause tumor eradication. J Immunol 2004;173:6753-9

Vesosky B, Hurwitz AA. Modulation of costimulation to enhance tumor immunity. Cancer Immunol Immunother 2003; $52: 663-9$

Wang YC, Zhu L, McHugh R, Sell KW, Selvaraj P. Expression of heat-stable antigen on tumor cells provides costimulation for tumor-specific $\mathrm{T}$ cell proliferation and cytotoxicity in mice. Eur J Immunol 1995;25:1163-7

Wolkers MC, Stoetter G, Vyth-Dreese FA, Schumacher TN. Redundancy of direct priming and cross-priming in tumorspecific CD8+ T cell responses. J Immunol 2001;167:3577 84

Yang JC, Sherry RM, Steinberg SM, Topalian SL, Schwartzentruber DJ, Hwu P, Seipp CA, Rogers-Freezer L, Morton KE, White DE, Liewehr DJ, Merino MJ, Rosenberg SA. Randomized study of high-dose and low-dose interleukin-2 in patients with metastatic renal cancer. J Clin Oncol 2003; 21:3127-32

Yei S, Bartholomew RM, Pezzoli P, Gutierrez A, Gouveia 
E, Bassett D, Soo Hoo W, Carlo DJ. Novel membrane-bound GM-CSF vaccines for the treatment of cancer: generation and evaluation of mbGM-CSF mouse B16F10 melanoma cell vaccine. Gene Ther 2002;9:1302-11
Zier K, Gansbacher B, Salvadori S. Preventing abnormalities in signal transduction of $T$ cells in cancer: the promise of cytokine gene therapy. Immunol Today 1996;17:39-45 